\title{
Impact of Foreign Direct Investment in Indian Banking Sector
}

\author{
M. Baladevi, G. Nedumaran, M. Manida
}

\begin{abstract}
This article sustains the level of impact on foreign direct venture has on the Indian banking sector in the wake of the extraordinary capital takeoff from the Indian economy during the recent global economic recession the credit crunch. Information which are secondary data nature were obtained from measurable announcements of the Central Bank of India. Results uncovered that there is a non-positive significant impact of outside direct venture on the value capital of the Indian financial area, there is a negative unimportant effect of remote direct speculation on the liquidity position of the Indian banking sector and there is a negative inconsequential effect of remote direct venture on the absolute resources of the Indian banking sector. It is prescribed that the Indian Government should pay attention to more the obligation of making an empowering domain for powerful, esteem including outside direct interest in the banking sector without losing the prerogative of sovereignty. It is additionally prescribed that officially existing foreign direct investment in India should to be supported and the Government should start to take a gander at outside direct venture from a more profound point of view. The quality and structure of outside direct speculation should now be seen from the viewpoint of interest in more extensive parts of the economy (i.e power, manufacturing, banking and export-oriented industries) and the utilization of nearby providers, as opposed to a disproportionate spotlight on extractive enterprises. An endeavor has been made through this paper to assess the FDI inflows in the retail area.
\end{abstract}

Keywords : Indian economy, foreign direct investment, banking sector.

\section{INTRODUCTION}

Today Indian Banks are as innovation smart as their partners in created nations. The focused and change power have prompted the rise of web, e-banking, ATM, credit card and mobile banking as well, so as to draw in and hold the customers by bank. Because of Liberalization, Privatization and Globalization mode, Indian banks going worldwide and numerous worldwide banks setting up business in India, the Indian financial framework is set to include

Revised Manuscript Received on October 15, 2019.

* Correspondence Author

Ms.M.BALADEVI, Ph.D. Research Scholar, Dept.of Commerce, Alagappa University, Karaikudi, India.

Dr.G.NEDUMARAN, Associate Professor, Dept.of Commerce, Alagappa University, Karaikudi, India

Mr. M.MANIDA, Ph.D. Research Scholar, Dept.of Commerce, Alagappa University, Karaikudi, India into an absolutely new level it will help the financial framework develop in quality going into what's to come. The financial division assumes a significant job in the monetary improvement of a nation. It supplies lifeblood -money that supports and encourages development in every one of the ventures. Genuine, money related assets in essence, can't guarantee business achievement, which requires capabilities on a few different fronts, including innovation, accessibility of gifted labor, well-overseen structure and a first rate focused system. FDI is an apparatus for financial development through its fortifying of local capital, efficiency and business. FDI additionally assumes an essential job in the up degree of innovation, aptitudes and administrative capacities in different areas of the economy. Remote Direct Investment as observed as a significant wellspring of non-obligation inflows and is expanding being looked for as a vehicle for innovation streams and as a methods for achieving aggressive effectiveness by making an important system of worldwide interconnections. FDI assumes an essential job in the economy since it doesn't just give chances to have nations to improve their financial advancement yet additionally opens new vistas to home nations to enhance their income by utilizing their optimal assets.

\section{FDI in Indian banks}

The conventional contention against foreign equity participation local organizations is that these organizations regularly include national and vital interests and consequently, operational and key control must be held to counteract a dominate or a buyout [Lam (1997)]. Until 1993, most Indian banks were 100 percent possessed by the focal government and private venture was permitted distinctly in a bunch of private banks conformed to the 1940s. Further, outside banks and money related organizations 
were permitted just 20 percent possession stakes in Indian banks. In 1993-94, nine new banks were framed in the private part and one co-usable bank was changed over to a private bank. Banks were allowed to issue Certificates of Deposits (CDs) and offer outside cash stores to Non-inhabitant Indians (NRIs) with swapping scale hazard borne by the banks. A noteworthy push towards progression happened in 1995-96 when India focused on the World Trade Organization (WTO) suggestions and loosened up the necessity to keep protecting the need segment from remote value interest. For the following five years, changes in the financial segment for the most part planned for permitting banks greater adaptability in the structure and promoting of items.

\section{FDI in banking sector can solve various problems of the overall banking sector:

$>$ Financial Products
$>$ Technical Developments in the
Foreign Markets
$>$ Problem of Inefficient Management
$>$ Non-performing Assets
$>$ Financial Instability
$>$ Poor Capitalization

\section{REVIEW OF LITERATURE}

Kunofiwa Tsaurai(2014), in his title "Banking Sector Development and Foreign Direct Investment. A Case of Botswana", has analyzed the study investigates if there is a causality relationship between banking sector development and FDI inflows in Botswana. Though quite a number of authors have written on the subject, there appears to be no consensus on the directional causality between banking sector development and FDI inflows into the host country. At the moment, three dominant perspectives exist regarding the relationship between banking sector development and FDI inflows into the host country. The first perspective says that banking sector development attracts FDI inflows into the host country. The second perspective suggests that there is a positive feedback effect between banking sector development and FDI inflows whilst the third perspective maintains that there is no direct causality relationship between the two variables. The results from this study are consistent with the third perspective that says there is no direct

causality relationship between banking sector development and FDI net inflows. This confirms that the long run relationship between banking sector development and FDI net inflows is an indirect one and the two set of variables affect each other indirectly through other factors in Botswana.

Mahesh kumar yadav, Dr. Bhupender kumar Dular (2017), in his title "A study of foreign direct investment and Indian banking sector" has analyzed the Indian Banks are as technology savvy as their counter parts in developed countries. The banking sector plays an important role in the economic development of a country. It supplies the lifeblood -money that supports and fosters growth in all the industries. FDI is a tool for economic growth through its strengthening of domestic capital, productivity and employment. FDI also plays a vital role in the up gradation of technology, skills and managerial capabilities in various sectors of the economy. Foreign Direct Investment as seen as an important source of non-debt inflows and is increasing being sought as a vehicle for technology flows and as a means of attaining competitive efficiency by creating a meaningful network of global inter-connections. This paper discusses the FDI Equity inflows in Service Sector in India and also highlights the top countries which are investing in the Service Sector in the form of FDI. In this paper an attempt is made to present the FDI inflows in sub sectors of Service Sector. Further, this paper also analyzes the FDI inflows in Banking Sector from January, 2000 to June, 2015.

\section{OBJECTIVES}

$>$ To study and analyze the Foreign Direct Investment inflows in Banking Sector.

$>$ To present the Foreign Direct Investment inflows in Banking Sector.

\section{METHODOLOGY}

Data: Data of No. of Foreign Branches, Foreign Business Turnover, Foreign Institutional Investment from year 2014-2019 is considered for the study. 
Data collection method: Secondary data from different web sites \& reports of SBI, Canara Bank and Bank of Baroda.

\section{DATA ANALYSIS AND INTERPRETATION}

TABLE 1: NO. OF FOREIGN BRANCHES

\begin{tabular}{|c|c|c|c|}
\hline \multirow{2}{*}{ Years } & \multicolumn{3}{|c|}{ STATE BANK OF INDIA } \\
\cline { 2 - 4 } & Numbers & $\begin{array}{c}\text { Increase/ } \\
\text { Decrease }\end{array}$ & GR (\%) \\
\hline $\mathbf{2 0 1 4 - 2 0 1 5}$ & 191 & -- & -- \\
\hline $\mathbf{2 0 1 5 - 2 0 1 6}$ & 198 & 7 & 3.66 \\
\hline $\mathbf{2 0 1 6 - 2 0 1 7}$ & 195 & -3 & -1.52 \\
\hline $\mathbf{2 0 1 7 - 2 0 1 8}$ & 206 & 11 & 5.64 \\
\hline $\mathbf{2 0 1 8 - 2 0 1 9}$ & 208 & 2 & 0.97 \\
\hline Total & 998 & & \\
\hline Mean & 199.6 & & \\
\hline SD & 7.23 & & \\
\hline CAGR\% & -0.01 & & \\
\hline
\end{tabular}

Source: SBI Annual Report, Computed

\section{Interpretation}

From Table 1, it could be seen that the Foreign branches /Offices in SBI was increasing between 191 in 2014-15 to 208 in 2018-19. The highest of Foreign branches /Offices of SBI in 208 in the year of 2018-19.Growth rate value in the year of $2015-16$ is $3.66 \%$ and the year of $2018-19$ is $0.97 \%$.

CHART: I

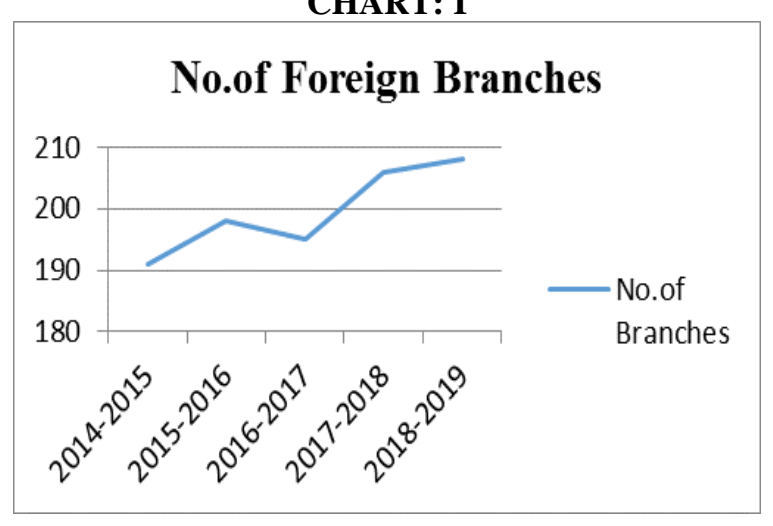

TABLE 2 : FOREIGN BUSINESS TURNOVER

\begin{tabular}{|c|c|c|c|}
\hline \multirow{2}{*}{ Years } & \multicolumn{3}{|c|}{ CANARA BANK } \\
\cline { 2 - 4 } & Turnover & $\begin{array}{c}\text { Increase/ } \\
\text { Decrease }\end{array}$ & GR (\%) \\
\hline $\mathbf{2 0 1 4 - 2 0 1 5}$ & 176274 & -- & -- \\
\hline $\mathbf{2 0 1 5 - 2 0 1 6}$ & 201860 & -25586 & 1.45 \\
\hline $\mathbf{2 0 1 6 - 2 0 1 7}$ & 235425 & -33565 & 1.67 \\
\hline $\mathbf{2 0 1 7 - 2 0 1 8}$ & 261469 & -26044 & 1.10 \\
\hline $\mathbf{2 0 1 8 - 2 0 1 9}$ & 257078 & 4391 & -0.17 \\
\hline Total & 1132106 & & \\
\hline
\end{tabular}

\begin{tabular}{|c|c|l|l|}
\hline Mean & 226421.2 & & \\
\hline SD & 36630.76 & & \\
\hline CAGR\% & -0.70832 & & \\
\hline
\end{tabular}

Source: Canara Bank Annual Report, Computed

\section{Interpretation}

From Table 2, it could be seen that the Foreign Business Turnover in Canara Bank was increasing between 176274 in 2014-15 to 257078 in 2018-19.The highest of Foreign Business Turnover of Canara Bank in 257078 in the year of 2018-19.Growth rate value in the year of 2015-16 is $1.45 \%$ and the year of $2018-19$ is $-0.17 \%$.

CHART: 2

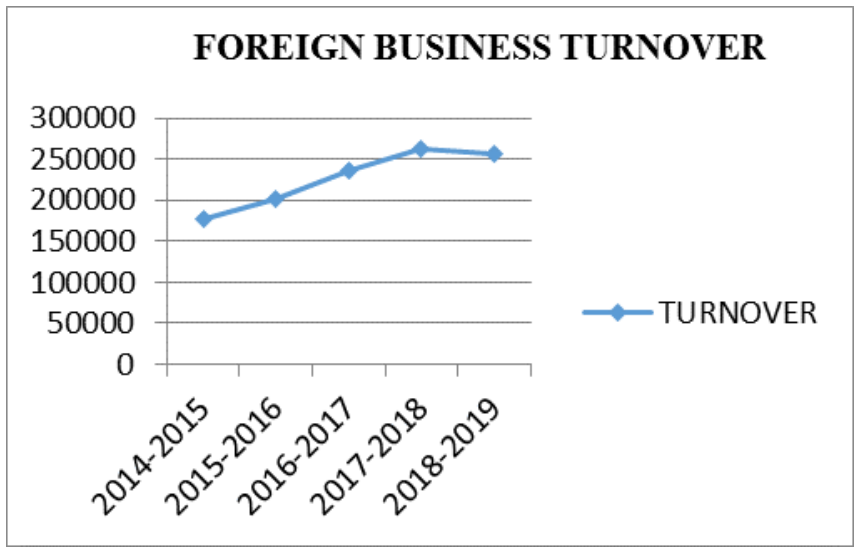

TABLE 3: FOREIGN INSTITUTIONAL INVESTORS

\begin{tabular}{|c|c|c|c|}
\hline \multirow{2}{*}{ Years } & \multicolumn{3}{|c|}{ BANK OF BARODA } \\
\cline { 2 - 4 } & FII & $\begin{array}{c}\text { Increase/ } \\
\text { Decrease }\end{array}$ & GR (\%) \\
\hline $\mathbf{2 0 1 4 - 2 0 1 5}$ & 346258 & -- & -- \\
\hline $\mathbf{2 0 1 5 - 2 0 1 6}$ & 308141 & 38117 & -1.10 \\
\hline $\mathbf{2 0 1 6 - 2 0 1 7}$ & 265465 & 42676 & -1.38 \\
\hline $\mathbf{2 0 1 7 - 2 0 1 8}$ & 124187 & 141278 & -5.32 \\
\hline $\mathbf{2 0 1 8 - 2 0 1 9}$ & 109275 & 14912 & -1.20 \\
\hline Total & 1153326 & & \\
\hline Mean & 230665.2 & & \\
\hline SD & 107991.2 & & \\
\hline CAGR\% & -0.20599 & & \\
\hline
\end{tabular}

\section{Interpretation}

From Table 3, it could be seen that the Foreign Institutional Investors in Bank of Baroda was Decreasing between 346258 in 2014-15 to 109275 in 2018-19.The highest of Foreign Institutional Investors in Bank of Baroda in 346258 in the year of 2014-15.Growth rate value in the year of $2015-16$ is $-1.10 \%$ and the year of $2018-19$ is -1.20 $\%$.

Published By:

Blue Eyes Intelligence Engineering \& Sciences Publication 


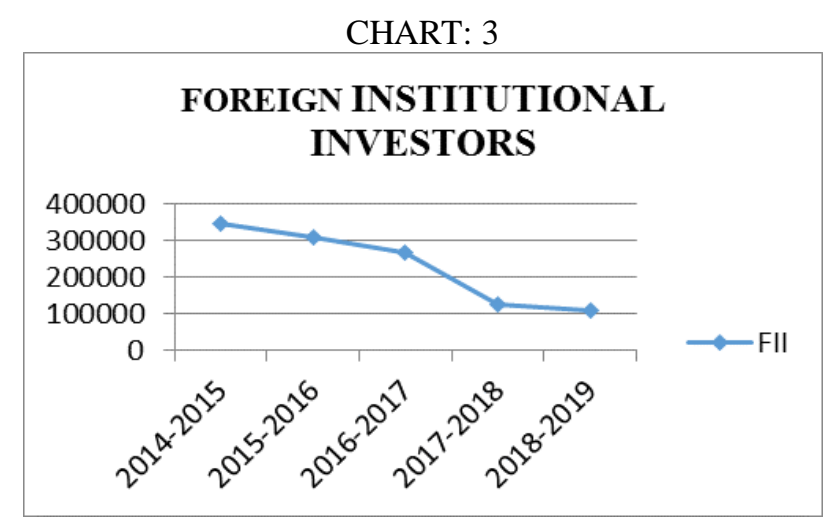

\section{Interpretation}

From Table 3, it could be seen that the Foreign Institutional Investors in Bank of Baroda was Decreasing between 346258 in 2014-15 to 109275 in 2018-19.The highest of Foreign Institutional Investors in Bank of Baroda in 346258 in the year of 2014-15. Growth rate value in the year of $2015-16$ is $-1.10 \%$ and the year of $2018-19$ is -1.20 $\%$.

\section{CONCLUSION}

FDI assumes an essential role in the economy by giving chances to have countries to upgrade their economical improvement. India is viewed as the third witticism favored speculation goal on the world. It is seen that Service sector is one of the commanding divisions in representation in more FDI inflows. The top nations putting resources into the type of FDI in Service Sector are Mauritius, Singapore and United Kingdom. FDI in Banking Sector takes care of different issues like Inefficient Management, Non-Performing Assets, Financial Instability and Poor Capitalization. Further, FDI in Banking Sector give advantages of Technology Transfer, Better Risk Management, Financial soundness, Innovative Products and Employment. Strangely, FDI inflows in Banking Sector have been expanding year by year.

\section{REFERENCES}

1. Dr. N. K. Sathya Pal Sharma, Prof. Krishna B. S.(2013), "Role of FDI in Banking, in generating wealth to Indian Economy", International Journal of Advancements in Research \& Technology, Volume 2, Issue 5, M ay-2013,pp.276-281.

2. Kunofiwa Tsaurai(2014), "Banking Sector Development and Foreign Direct Investment. A Case of Botswana”, Risk governance \& control: financial markets \& institutions / Volume: 4, Issue: 3, 2014, pp.44-50.

3. Ajay Massand, Gopalakrishna B.V.(2014), "Foreign Direct Investment in Indian Banking Sector: Trends, Opportunities and Impact", International Journal of Management, Volume: 2 Number: 2 December 2014.

4. Malla Reddy. M (2014), "Foreign Direct Investment in Indian Banking Sector: A Study", International Journal of Advance Research in Computer Science and Management Studies, Volume: 2, Issue: 10, October: 2014, pp.77-86.

5. Abhishek Vijaykumar Vyas(2015), "An Analytical Study of FDI in India", International Journal of Scientific and Research Publications, Volume 5, Issue 10, October 2015,pp.1-30.

6. Mahesh kumar yadav, Dr. Bhupender kumar Dular (2017), "A study of foreign direct investment and Indian banking sector" International Journal of Commerce and Management Research, Volume 3; Issue 3; March 2017; Page No. 27-30.

7. https://shodhganga.inflibnet.ac
8. https://canarabank.com

9. https://www.bankofbaroda.in

10. https://www.sbi.co.in 